\title{
Art, History and Discipline in the Eighteenth-Century German University
}

\author{
Anne-Marie Link
}

Volume 28, 2001-2003

Art History Inside and Outside the University

L'histoire de l'art à l'université et hors de l'université

URI : https://id.erudit.org/iderudit/1069780ar

DOI : https://doi.org/10.7202/1069780ar

\section{Aller au sommaire du numéro}

\section{Éditeur(s)}

UAAC-AAUC (University Art Association of Canada | Association d'art des universités du Canada)

\section{ISSN}

0315-9906 (imprimé)

1918-4778 (numérique)

\section{Découvrir la revue}

Citer cet article

Link, A.-M. (2001). Art, History and Discipline in the Eighteenth-Century German University. RACAR : Revue d'art canadienne / Canadian Art Review, 28, 19-28. https://doi.org/10.7202/1069780ar

\section{Résumé de l'article}

Cet article examine les liens entre un texte d'histoire de l'art écrit vers la fin du dix-huitième siècle et l'institution dans laquelle et pour laquelle il a été conçu, à savoir l'Université de Göttingen (la "Georgia Augusta ») en Allemagne du Nord. Bien que l'objectif principal de cet essai soit d'analyser un cas précoce (peut-être même le premier cas ?) par le biais duquel l'histoire de l'art devint une discipline académique, nous y abordons plus largement le rôle de la discipline dans la formation de l'érudition universitaire moderne. Nous voulons montrer que la constitution de l'histoire de l'art comme discipline dans cette institution allemande, considérée alors comme la plus moderne de son époque, était étroitement liée à un modèle " progressif " et " scientifique " d'érudition, né de préoccupations théoriques développées par ses historiens de profession, parmi lesquels on retrouve Johann Dominicus Fiorillo, un artiste et un membre du corps professoral. Celui-ci collabora à une série de volumes sur l'histoire des arts et sciences parrainée par l'Université elle-même par la publication entre 1798 et 1808 de cinq volumes de son histoire de l'art. Cette série avait été pensée comme un «monument » approprié pour la fin d'un siecle éclairé et le début d'un siècle nouveau et visait à circonscrire la culture de " notre coin de terre " d'une manière aussi " progressive " et " scientifique " que possible. Notre article s'intéresse surtout aux moyens pris par une histoire de l'art post-winckelmannienne, mais antérieure au milieu du dix-neuvième siècle, visant à intégrer ces analyses de la culture à une époque qui voyait l'épanouissement des sciences humaines, une connaissance croissante des " autres » cultures et une nouvelle conception théorique de l'histoire. Par conséquent, l'histoire de l'art de Fiorillo doit être considérée en termes de la particularité propre du lieu où il l'a écrite, et cela suppose que la constitution d'une histoire de l'art universitaire doit être nécessairement considérée dans la production du savoir culturel de l'Université de Göttingen (et du Siècle des Lumières) sur l'identité humaine et européenne. L'histoire de l'art comme nouvelle discipline dont les objectifs étaient justement d'archiver " notre culture ", peut ainsi être reconnue comme une partie prenante du "master narrative " historiciste, dominant dans l'érudition universitaire occidentale et dans la formation de la modernité européenne.
Tous droits réservés (C) UAAC-AAUC (University Art Association of Canada | Association d'art des universités du Canada), 2004
Ce document est protégé par la loi sur le droit d'auteur. L'utilisation des services d'Érudit (y compris la reproduction) est assujettie à sa politique d'utilisation que vous pouvez consulter en ligne.

https://apropos.erudit.org/fr/usagers/politique-dutilisation/ 


\title{
Art, History and Discipline in the Eighteenth-Century German University
}

\author{
AnNe-Marde Link, Augustana University Coli.fGe
}

\section{Résumé}

Cet article examine les liens entre un texte d'histoire de l'art écrit vers la fin du dix-huitième siècle et l'institution dans laquelle et pour laquelle il a été conçu, à savoir l'Université de Göttingen (la « Georgia Augusta ») en Allemagne du Nord. Bien que l'objectif principal de cet essai soit d'analyser un cas précoce (peut-être même le premier cas?) par le biais duquel l'histoire de l'art devint une discipline académique, nous y abordons plus largement le rôle de la discipline dans la formation de l'érudition universitaire moderne. Nous voulons montrer que la constitution de l'histoire de l'art comme discipline dans cette institution allemande, considérée alors comme la plus moderne de son époque, était étroitement liée à un modèle « progressif » et « scientifique » d'érudition, né de préoccupations théoriques développées par ses historiens de profession, parmi lesquels on retrouve Johann Dominicus Fiorillo, un artiste et un membre du corps professoral. Celui-ci collabora à une série de volumes sur l'histoire des arts et sciences parrainée par l'Université elle-même par la publication entre 1798 et 1808 de cinq volumes de son histoire de l'art. Cette série avait été pensée comme un «monument» approprié pour la fin d'un siecle éclairé et le début d'un siècle nouveau et visait à circonscrire la culture de « notre coin de terre » d'une manière aussi « progressive » et « scientifique » que possible. Notre article s'intéresse surtout aux moyens pris par une histoire de l'art post-winckelmannienne, mais antérieure au milieu du dix-neuvième siècle, visant à intégrer ces analyses de la culture à une époque qui voyait l'épanouissement des sciences humaines, une connaissance croissante des « autres 》 cultures et une nouvelle conception théorique de l'histoire. Par conséquent, l'histoire de l'art de Fiorillo doit être considérée en termes de la particularité propre du lieu où il l'a écrite, et cela suppose que la constitution d'une histoire de l'art universitaire doit être nécessairement considérée dans la production du savoir culturel de l'Université de Göttingen (et du Siècle des Lumières) sur l'identité humaine et européenne. L'histoire de l'art comme nouvelle discipline dont les objectifs étaient justement d'archiver « notre culture », peut ainsi être reconnue comme une partie prenante du « master narrative » historiciste, dominant dans l'érudition universitaire occidentale et dans la formation de la modernité européenne.
I t is generally accepted that Johann Joachim Winckelmann was the first art historian to attempt a history of art (rather than of artists) in his 1764 History of the Art of Antiquity (Geschichte der Kunst des Alterthums). ${ }^{1}$ This publication, in which Winckelmann wrote a history based upon the art objects of antiquity and their relationship to Beauty through an historical model of rise and decline, has consequently gained him an important reputation for a new historically based writing about art and culture. This reputation has, however, tended to obscure the fact that Winckelmann's historical interest was not an isolated one for his time, and not even an unusually sophisticated one, but rather part of a larger development of an historical consciousness now accepted as germane to Western modernity. ${ }^{2}$ This larger development during the eighteenth century has been linked particularly with German scholars at Protestant universities and academies, ${ }^{3}$ sites far removed from the Catholic Rome in which Winckelmann lived and worked. In Germany, university scholars were engaged with a reorientation to an understanding and usage of the past, and it is a recognition of this reorientation's importance for the academic discipline of art history in that country which will be argued for here. This suggested shift thus not only flattens outs Winckelmann's work but also aims at integrating institutional practices and the development of academic discipline into eighteenth-century art historical historiography. It should be remembered that Winckelmann's work as an art historian came from the position of a "free" scholar, that is, one not employed by an educational institution. Winckelmann himself quite clearly drew the distinction between his position as a free scholar and what he viewed as the undesirable position of an educational "pedant", claiming that only in Italy could a scholar avoid the pitfalls associated with the stifling educational institutional life of his native Germany. ${ }^{4}$ While much of Winckelmann's characterization of the moribund state of higher education in Germany may be true, it is so only in part, for shortly after the time in which Winckelmann was writing his works, the first university teaching of art history would be instituted in Germany, and it would be the university that would produce art historical texts linking that discipline to the larger concerns of the new conceptions of history being forged in the latter decades of the eighteenth century. $^{5}$

The present essay is a consideration of these developments, and also an analysis that places them in the context of questions regarding the production of historical knowledge in which early academic art historical texts might have participated. What I am particularly interested in is the "history" side of the "art history" equation, not in the sense of a history of the idea of an art independent from history, ${ }^{6}$ but in terms of the intersection of late eighteenth-century concepts of history with a history of art. This intersection, which takes place during the perceived shift from Enlightenment histories to nineteenth-century historicism, ${ }^{7}$ is seen as critical to the writing of a university-based 
art history. It has recently been pointed out - perhaps with some exaggeration - that the lack of interest in Enlightenment historiography in general is an "intellectual embarrassment", limited mainly to the evaluation of the degree of "modernity" (that is, the use of a scientific model) of particular authors or texts, ${ }^{8}$ and something similar might be said about art historical texts of this period. Not only are they little read, but the idea of history that was such a critical part of their mandate is almost entirely unexplored. In the present analysis I therefore propose to focus on what I consider a substantial art historical series produced in Germany during the years 1798 to 1808, with the specific intent of considering this series within the wider parameters of both the place in which it was produced - the German university - and the academic enquiry in which it participated, that is, the knowledge and understanding of the present through a study of the past.

The text under consideration was written by the painter-turnedacademic Johann Dominicus Fiorillo (1748-1821) ${ }^{9}$ at the university at Göttingen (the Georgia Augusta) (fig. 1) between the years 1798 and 1808. Entitled Geschichte der zeichnenden Künste von ihrer Wiederauflebung bis auf die neuesten Zeiten (History of the Arts from their Revival to the Present Time), the series consisted of histories of painting and the graphic arts of Rome and Tuscany (volume 1, 1798), of Venice, Lombardy, Sicily, Liguria and Piedmont (volume 2, 1801), of France (volume 3, 1803, 1805), of Spain (volume 4, 1806) and of Great Britain (volume 5, 1808)..$^{10}$ The German-born but Italian-trained Fiorillo had first served the university as curator of its print collection and then as lecturer on the history of art within the faculty of Philosophy. He would later be appointed the first full professor of the history of art in 1813. Fiorillo was a prolific writer on his subject, producing monographs and short articles throughout the decade of the $1780 \mathrm{~s},{ }^{11}$ followed by what would be recognized as his magnum opus. His five-volume Geschichte represents not only the kind of art history that Fiorillo taught his students, but also the newly forged relation between art history and the rest of the university, for his text was quite specifically conceived as part of a comprehensive fifty-seven volume historical series published under the editorship of Johann Gottfried Eichhorn, a Göttingen professor of philosophy and biblical scholar. The series was entitled Geschichte der Künste und Wissenschaften seit der Wiederherstellung derselben bis an das Ende des achtzehnten Jahrhunderts (History of the Arts and Sciences from their Reestablishment to the End of the Eighteenth Century) ${ }^{12}$ and was to represent the best work of what was considered an innovative faculty, ${ }^{13}$ with Fiorillo taking his place among them. The presence of an art historical text in this larger university project ${ }^{14}$ thus marks a change from earlier art histories that were largely written by and for cognoscenti, collectors, art theorists and art- ists, and brings us to the kind of art history with which we today are most familiar, that is, an art history produced almost exclusively by university professors.

Although Fiorillo's work has generally been considered as transitional between Winckelmann's art history and the "great" art historians of the nineteenth century, there have been some recent attempts in German art historical circles to establish him as a "forefather" of art historical writing. This recent scholarship has focused on both the recovery of a lost reputation and a consequent close reading of Fiorillo's work; it has, however, tended to pass over the relationship between the production of an art history and the institution in which it was produced. A main concern, instead, has been an attempt to "correctly" place man and work into an historical period in which they might "fit". ${ }^{15}$ Since Fiorillo's work was produced roughly during the beginning years of what is called the Romantic period, much of the scholarly work regarding him has been concerned with determining his influence (or lack thereof) on/by the Romantic stirrings of turn-of-the-century Germany. ${ }^{16}$ This interest is tied very much to the illustriousness of some of Fiorillo's pupils, who included the nineteenth-century art historian Carl Friedrich von Rumohr and the romantic writers Tieck and Wackenroder with their interest in medieval revival and German nationalism. In addition, since Fiorillo was to a limited extent involved also with the Schlegels and with Goethe, he has been considered in terms of the classic-romantic debate of the late eighteenth century. Yet almost all of these considerations leave out the university of Göttingen entirely, thus severing Fiorillo's multi-volumed opus from the institution that produced it, and shurcing down the interesting possibility that art history as a discipline might have been more germane to that university's self-proclaimed "modernity" and "progressiveness" (and, hence, to these concepts in a larger sense) than previously recognized.

To understand both the university project and art history's role within it, it is first necessary to look briefly at the Georgia Augusta itself and to those circumstances that made up its singularity, for it seems to have been the first university to include art history as relevant to its programming aims and, hence, to what it would claim as its modernity. The university at Göttingen was recognized in its own time as embodying the "new" and the modern (in which the modern represented the anti-traditional), ${ }^{17}$ a function related first of all to the university's newness in terms of age, for it had been founded in 1734 (officially opened in 1737), making it one of only three German universities (the others being Breslau and Erlangen) to be established in the eighteenth century. It was also a Protestant university, claiming to be interested in new secular knowledges rather than the furtherance of religious orthodoxy, as in the case of Germany's Catholic universities. Another claim to modernity came from the university's close relationship to what many 
LINK / Art, History and Discipline in the Eighteenth-Century German University

Figure I. J. P. Kaltenhöfer, View of Göttingen and its University. Engraving, $10.3 \times 5.4 \mathrm{~cm}$. (Photo: reproduced from Johann Stephan Pütter, Versuch einer academischen Gelehrten-Geschichte von der Georg-August-Universität zu Göttingen, Göttingen, 1765, I. Courtesy of the Bruce Peel Special Collections Library, University of Alberta).

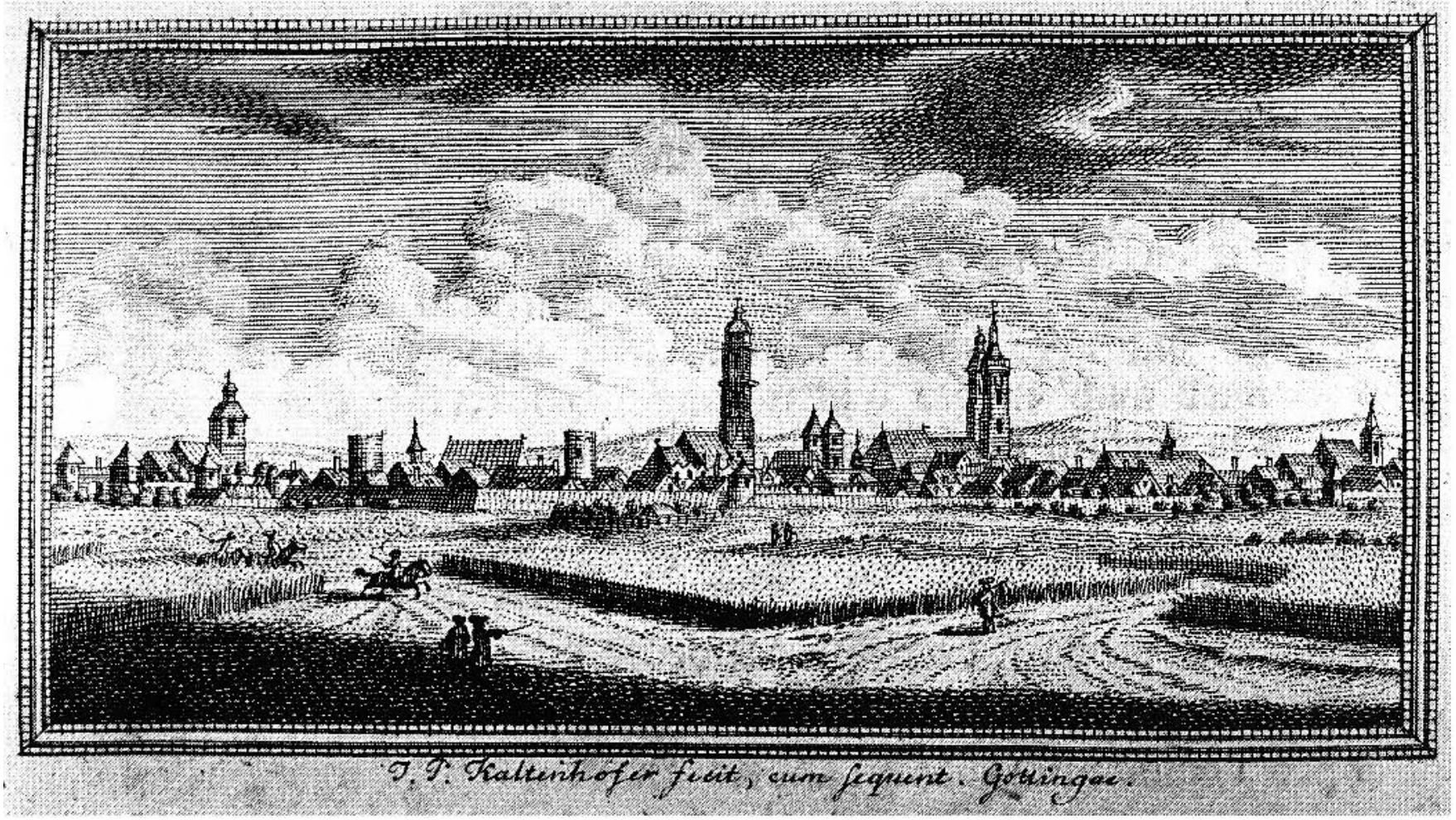

German intellectuals believed to be the anti-traditional character of eighteenth-century British thought, for the university had been founded through the administration of George II, king of England and also Elector of Hanover (hence, the name "Georgia Augusta"). ${ }^{18}$ 'This identity of the new and the modern raises the question of what this claim might have meant for observers of the time. While there is no doubt that the university of Göttingen's claims are in tune with our notions of the eighteenth century's enlightened pursuit of secular knowledge, ${ }^{19}$ there is also the prosaic fact that eighteenth-century universities, at least those that counted themselves successful, did not create curricula according to purely theoretical concerns. This is particularly true of eighteenth-century Germany, where the beginning of the century saw a serious crisis in the commitment to the idea of university education itself, a crisis essentially unresolved even by the end of the century. ${ }^{20} \mathrm{~A}$ university education, rather surprisingly for an age that has been represented as being dedicated to the pursuit of reason and knowledge, was in fact criticized throughout the century as not relevant enough to those needing to find gainful employment. Thus, the eighteenth-century university was frequently under attack, and it seems relevant to look at curriculum innovations as responses to this attack rather than only in terms of a history of ideas or Zeitgeist.
At Göttingen, the response to the charges of the outdated and irrelevant university was the development of an anti-traditional curriculum that would attract students, particularly feepaying students, to a new university. The curriculum thus became a recruiting device, consciously rejecting the scholasticism and pedagogy of the seventeenth-century universities, ${ }^{21}$ as well as their essentially ecclesiastical mandate. In conjunction with this rejection of traditional learning was also the pursuit of only the most original and productive thinkers for the university's professoriate, rather than the relayers of accepted knowledge associated with the traditional universiry. ${ }^{22}$ It was these men (for they were all men) who would create new knowledge, and in its recruiting drive, begun under the leadership of its first president, Gerlach Adolf von Münchhausen, the Georgia Augusta had been particularly successful in luring to Göttingen some of Germany's leading professors. Once at the university, professors were guaranteed complete freedom in both tcaching and research; research, in fact, was expected of all faculty, and it was in order to relay the spirit of enquiry that the teaching form of the seminar was first developed at the university of Göttingen. ${ }^{23}$

Göttingen's new curriculum and teaching methods were geared to that social group from which the university believed it had the most to gain, the fee-paying sons of the large German nobility and upper professional classes, ${ }^{24}$ a fact that should be 
kept in mind when considering the later role of art history at the university. The university's own power and authority were closely linked to the house of Hanover (and thus the British king), and its central concern throughout the century would remain that of satisfying the educational needs of Germany's large nobility, as well as the newer and increasingly influential official and professional classes. The needs of this new "enlightened" generation included professionalization, particularly in the field of law; however, the acquisition of those accomplishments traditionally associated with ruling-class culture also retained their importance. These ranged from horsemanship (which had a particularly strong presence at Göttingen) to what Pierre Bourdieu has identified, in his study of educational institutions, as a gentlemanly "type of relationship to language and culture", 25 a relationship enhanced by some knowledge of the visual arts and their history. Part of the modernity of the university, in fact, lay precisely in its combining of the tradition of the honnete homme - Bourdieu's "games of distinction"26 - with a new emphasis on professionalization.

Although three (Law, Medicine, Theology) of the four faculties found at eighteenth-century universities were geared to career concerns, it was also recognized that the "truly educated" modern gentleman needed a balance to career-based knowledge. This was to be provided by the remaining faculty of the university, that of Philosophy, which included essentially everything else, such as the natural sciences and the new discipline of history. History, in particular, would become an important component of a new curriculum, making the Georgia Augusta the "most modern university in Germany". ${ }^{27}$ Here, an understanding of historical development was increasingly seen as necessary to an understanding of contemporary culture and society, so that the true object of history became what Michel Foucault has argued was that gencrally of the later eighteenth century, that is, the human being. ${ }^{28}$ It is in the context of the shift to the human as both subject and object that Foucault has placed the "invention" of the human sciences, and it is also in this context that the various human histories as conceived and taught at Göttingen - from the theories of race proposed by Christoph Meiners and Johann Friedrich Blumenbach (who would coin the word "Caucasian" in the 1790s ${ }^{29}$ to new theories of history as interpreted by Johann Christoph Gatterer and August Ludwig von Schlözer ${ }^{30}$ to a new art history as conceived by Fiorillo - can be considered.

Martin Bernal, in his controversial Black Athena, has argued that the university of Göttingen was the "embryo of all later, modern, diversified and professional universities", and maintains that the university's knowledge-making was essentially steeped in, and constitutive of, ethnicity and racism. ${ }^{31}$ According to Bernal, the university served as a conduit for what he considers racist Anglo thought regarding human culture on the continent, and he therefore points to Göttingen as playing an important role in the production of cultural knowledge about what it was to be both human and European. Bernal sees this type of cultural/social knowledge as being both produced and disseminated through elite university practice, such as Göttingen's reforms of academic freedom and teaching innovations like the seminar. While Bernal's observations regarding the university of Göttingen are fairly brief (his main concern is with a much larger and contested argument ${ }^{32}$ regarding what he believes is the West's essentially erroneous and racially motivated manufacture of its own Greek heritage), his observations do point to some interesting directions when considering the History of the Arts and Sciences in general, and Fiorillo's contribution in particular.

As Bernal claims, Göttingen was considered a European leader in the researching of human culture through the modern university practices of seminar teaching and faculty research, and in the dissemination of that research to a wider public through publishing programmes. Much of that research was dedicated to the understanding of the human subject, particularly the contemporary European subject against a spotty background of a larger pantheon of world cultures, an aim which accords with that set out in the introduction to the fifty-seven volumes of Göttingen's History of the Arts and Sciences from their Re-establishment to the End of the Eighteenth Century. Here is found the central question which the histories within it were to answer: "How did our part of the earth arrive at its present culture, and how did our society progress from a state of rawness through to the present stages of improvement, ennoblement and refinement?" 33 The histories it contained, and which were to clarify the nature of "our" present culture (histories such as those of "culture and literature", "Greek and Roman literature", "Philosophy", "Mathematics", "War", technology and the arts), ${ }^{34}$ had their foundation in the university's system of teaching, where they contributed to varying forms of the large concept of a "universal history" in its eighteenth-century version, which purported to study "all of [humankind's] ways, from land to land, from folk to folk, from age to age" according to "successive origins, ennoblements and deteriorations". ${ }^{35}$ In actual practice, the various "lands," "folk" and "humankind" studied were most often those of Europe itself, for not only were they the most accessible for research, but they could contribute most greatly to the understanding of the contemporary European state.

If we turn back to the massive History of the Arts and Sciences and narrow our focus to Fiorillo's art history within it, this European orientation becomes clear, although, as shall be seen, this did not preclude the occasional incorporation of what was believed to be known about non-European cultures. Fiorillo's 
broad-ranging observations were, in fact, the base upon which he would make claims for the originality and legitimacy of his work, for his art history was to be an academic contribution, as befitted his role as professor. In the words of Christoph Meiners, Fiorillo was indeed a "true" professor, that is, one who "knows the theory and history of his subject". ${ }^{36}$ Fiorillo, too, viewed his position in terms of the university for, although his original training had been as an artist, he observed that the university was not an art academy and therefore required a different kind of work. ${ }^{37}$ For him, this would be a history of art written according to the "light that has in our time already illuminated historical and philosophical enquiry". ${ }^{38} \mathrm{He}$ thus took to task the current state of art historical studies, which he claimed consisted only of a "very great mass" of artist biographies, dictionaries of art and descriptions of galleries, cabinets and collections, as well as the proceedings of art academies, anecdotes, criticism and "news" about art. ${ }^{39}$ With these sentiments Fiorillo echoed Gatterer, who had written of his desire to leave behind "geschmacklose Kompilatoren" ("tasteless compilations") and to pursue instead a comprehensive overview, which would form a "true history". ${ }^{40}$ Fiorillo, too, would go on to dismiss as useless, for his time and age, the compilations of Durand, Rollin and Felibien, and would find only the art historical work of his countryman, the "great" Johann Joachim Winckelmann, as relevant to his own art historical project. ${ }^{41}$

This project, like Winckelmann's, would display notions of cultural progress; however, it also attempted to stake a territory beyond Winckelmann's history of Greek art through a concentration on the present-day period. This is not to say that Fiorillo rejected Winckelmann's work on the Greeks, but perhaps rather the opposite, that the "great" Winckelmann had already said all there was to say about the Greek art that Fiorillo accepted as seminal to Western culture. Fiorillo's task was, thus, differently oriented than Winckelmann's, for he attempted a history of art in terms of a continuing process and, therefore, could not organize his history in the Winckelmannian (and also Vasarian) terms of self-limiting cycles. Instead of trying to account for the perfections reached by the past, Fiorillo's task was to consider modern European art as the product of a general and continuing progress of humankind and as it was being mapped by his contemporaries. ${ }^{42}$

Fiorillo's aims are most clearly laid out in the introduction to his multi-volumed work, in which he begins his history of art not with a question related specifically to art or to artists, but one indebted to the larger questions being asked by the practitioners of the new historical thinking. The question he posed asked whether all of humanity might have had a common ancestor (an Urfolk) from which all arts and sciences simultaneously originated, or whether various groups might have developed the arts and sciences concurrently, yet independently of each other. ${ }^{43}$ It is a question that indicates Fiorillo's reliance on the anthropologically, racially and historically based endeavours of his university colleagues, and his answering of it will also display his reliance on their ideas regarding the importance of linkages and systems - rather than ecclesiastic or dynastic events when it came to studying culture via its artefacts. Fiorillo conceived of these linkages in terms of a structure, so that meaning, as in the Linnaean system recently developed for natural history, was derived from the structure itself, rather than any one individual part of it. Thus, while Fiorillo conceded that the life of the artist, as the traditional basis for histories of art, was still important to him, the minute details of the artist's life were not. Instead of scrutinizing the life of the artist as an independent entity, he looked to linkages berween artists - those of place, style and particularly school - as the focus of his work, and it is these connections that would form the structure and also the meaning of his history. Close connoisseurial looking no longer "worked" for Fiorillo, who needed instead to look large (he writes of his "comprehensive overview") 44 in order to see the entire structure of his history of art with all its influences, exchanges, patterns and movements.

He claimed that this structurally based overview was necessary to the construction of a "general history" and that, conversely, it was also this general history that was necessary to a true history of art. ${ }^{45}$ General history accepted the possibility of different rates of the "civilizing" process concurrently taking place, so that, for instance, the South Sea Islanders may still be in a "raw" state while "we" have progressed to a more "civilized" state. ${ }^{46}$ In addition, a culture with an "advanced" state in the arts and sciences could, in fact, hasten the process in other cultures through direct contact, a notion, of course, critical to colonizing powers and one which demonstrated the importance of the linkages on which Fiorillo based his history. ${ }^{47}$ Fiorillo's observations regarding the "civilized" and "not-yet-civilized" could not have been made before the eighteenth century explosion of publications "revealing" and making accessible to scholars the "rest of the world". It is not surprising that Fiorillo would make use of such publications, for not only were they well represented in Göttingen's famous library (fig. 2), ${ }^{48}$ but they were also the main sources for much of the new work being produced at Göttingen. Meiners, for instance, relied almost entirely on travel literature for his research into the categories of humanity, ${ }^{49}$ and Blumenbach maintained a close correspondence with Joseph Banks, believing Banks' collection of voyage accounts as essential to the formation of his theory of races. ${ }^{50}$ Fiorillo's art history is no exception to this academic interest in the discoveries of the time. He names, for instance, Captain Cook's Travels and Voyage to the Northern Hemisphere, Meares' Voyage from China to the Northwest Coast of America, Portlock's Voyage round the World and Forster's Observations made during a 
Figure 2. J. P. Kaltenhöfer, Library of the Georg-August University. Engraving, $10.6 \times 4.7 \mathrm{~cm}$. (Photo: reproduced from Johann Stephan Pütter, Versuch einer academischen Gelehrten-Geschichte von der Georg-August-Universität zu Göttingen, Göttingen, 1765, I. Courtesy of the Bruce Peel Special Collections Library, University of Alberta).

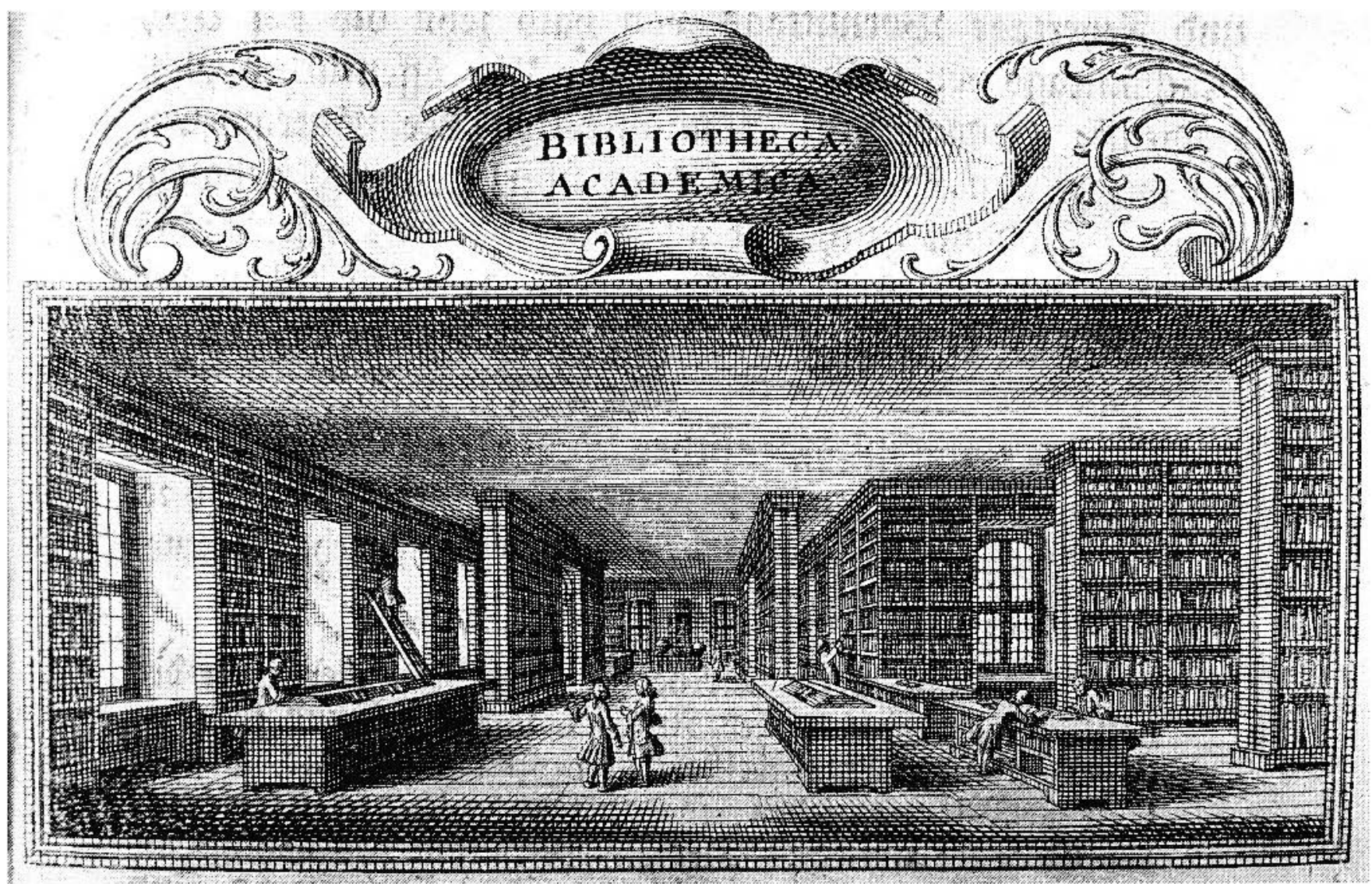

Voyage round the World ${ }^{51}$ as texts he had found particularly pertinent both to "explaining" a history of art and also to the explaining of the present state of "our culture". 52 For Fiorillo, the travel writings provided modern and "scientific" (wissenschaftliche) proof of what he believed to be true, that is, that there exist natural human tendencies to imitation, representation and ornamentation, tendencies that could then be charted in terms of their "progress" toward technical and aesthetic perfection. Technical and aesthetic achievements (judged always according to Western standards), were in turn the signs of the level of "civilization" and "humanity" reached by varying peoples. The travel writings, with their descriptions and illustrations of the objects and marks made by "raw peoples" thus provided to Fiorillo both demonstrable proof of, and a measurable distance between, the visual culture of "primitive" peoples - Fiorillo calls them "childlike people" ("kindischen Menschen") 53 - and the advanced culture of "ourselves".

In addition to providing information about the beginnings of art and culture, eighteenth-century travel writings were also interpreted by Fiorillo as endorsements to the claims of Western art theory as he had learned it in the European art academy tradition. He pointed out, for instance, that Cook, Meares and Portlock all noted the preference for the colour red by the "raw peoples" of Van Diemans Land (Tasmania) and of America, a preference Fiorillo interpreted as a primitive tendency to prefer strong colour over the more civilized concern with form. ${ }^{54} \mathrm{He}$ upheld the view that art had begun with a simple outline, which was then coloured in with a solid monochromatic colour "undoubtedly the simplest and oldest form of painting" - and which had later "progressed" to greater subtleties. 55 Since the preference for form could only be regarded by Fiorillo as a "progression" to the liking of colour (following the accepted notions of seventeenth- and eighteenth-century art theorists like De Piles), the travel writings served as a "proof" to what he already believed and had always taught. Fiorillo could therefore "scientifically" claim that accomplished representations of form were, indeed, only to be found in those cultures that have advanced to "skilled/practiced senses" ("geübtere Sinne") - cultures like "our" own. 56 Thus, it is only in "our" kind of culture that one finds the ability to represent three-dimensional form perfectly, a result of intelligent observation, technical mastery and technological advance. A perfect three-dimensional mime- 
sis of ideal forms as practiced in eighteenth-century European visual culture was thereby given meaning in terms of its contrast to the two-dimensional representation Fiorillo now "knows" is typical of "raw peoples". For Fiorillo, it was the now-proven presence of "raw peoples" and their artefacts that was of importance, for not only did they provide proof of "beginnings", but they also rendered the unanswerable question of whether there was a single Urfolk or several actually irrelevant to the "truths" of his argument. In either case - separate beginnings for separate races or one beginning for all - the "truth" was still the same, that is, all beginnings are represented by a "primitive" state of the arts which then develops and progresses, as a people develops and progresses, into aesthetic and technological mastery.

Fiorillo's ultimate interest, however, was not in "other" cultures, but in "our" own, with his comments about the findings of travellers providing a scientifically objective apologia and introduction to what would form the most lengthy part of his contribution to the Georgia Augusta's collaborative project. This was a detailed and often derivative - notwithstanding Fiorillo's claims to originality - discussion of the schools of art found in Europe since the time of the Renaissance. Having explained his theory and methods in his introduction, Fiorillo began the body of his study with a synopsis of the fate of the arts from Constantine to Cimabue (an era he regarded, in a traditional manner, as one of decline due to barbaric and Arabic invasion), and then continued with the arts belonging to "modern history". Beginning with the Renaissance, he divided modern time into three major periods ("Hauptperioden"): from Cimabue to Raphael, from Raphael to the Caracci and from the Caracci to Mengs (the latter a choice clearly influenced by the writings of Winckelmann). ${ }^{57}$ While it is clear that Fiorillo proposed his periods based on the accepted belief in the superiority of the classical tradition and its history, it is in his consideration of these divisions where he attempts to align his work with the synthesizing endeavours of his university contemporaries. He wrote, for instance, that the arts are the sisters of the sciences, that one cannot make progress without the other, that the history of their "Wachstum und Verfall" ("increase and decline") was always and irrevocably related to the history of religion, technology and political revolution, and that it was according to these factors that divisions must be instituted. ${ }^{58}$

A history of art, for Fiorillo, was therefore to be achieved by enhancing existing art historical "compilations" with an account of technologies, beliefs, social and political institutions and the connections between them; accordingly, Fiorillo organized his discussion of the various schools of painting first into what he considered coherent geographical regions, beginning with Italy (the schools of Rome, Florence, Venice, Lombardy, Ferrara, Modena, Bologna and "the rest") and moving on to France, Spain and Great Britain. Although the notion of schools of European art had been used by others, specifically Luigi Lanzi in his Storia pittorica dell'Italia (1789) - a work wellknown to Fiorillo - Fiorillo's usage of the concept indicates his attempts to construct what he called a more "useful" structure of schools of art, one which he claimed would provide a comprehensive understanding of the whole of modern art culture. ${ }^{59}$ Fiorillo made the point that Lanzi's writing about the visual arts had focused too much on schools in isolation from each other, a system that had led to a misleading "overabundance" of especially Italian schools. ${ }^{60}$ For Fiorillo, only demonstrable differences in climate, religion and institutions could produce true schools that were sufficiently distinct from each other to represent the stages of European culture - whether they be considered at regional, national or international levels - that essentially formed the core of his history. In order to achieve his useful structure, Fiorillo relied on his system of "Werwandschaft und Verkettung" 61 ("relationship and linkage") between schools in order to ascertain the components which made up the direction of change. Therefore, in his discussion of the Venetian school, for instance, his concern was to first ascertain the "seed" of that school by discarding dubious accounts (defined as those that could not be verified by other accounts) and replacing them with a study of what could be known regarding the social, political and religious circumstances out of which the school had formed. Out of this matrix, Fiorillo could demonstrate the essential progressive quality of Venetian art as it moved to ever greater illusionistic and technological mastery, in line with increasingly progressive advances in other areas of Venetian life, such as politics and trade. By adding to the more standard discussions of artists' lives and work (although these still form the majority of his texts) details of systems of patronage, rulers, economics, master-student influences and the "linkages" between these (as when he considered the case of French artists who might have been in Italy during the fifteenth century), Fiorillo was able to construct what he regarded as a useful history of painting which could take its place alongside the histories being produced by his colleagues. In addition, his practice of combining the many separate details that had appeared in other histories of art - particularly in Vasari and Lanzi - with a new network of references and asides outlining political and social circumstances resulted in a rext visually approximating the heavily referenced works of his colleagues.

Fiorillo's scholarly history of art, as he constructed its linkages through the Italian, French, Spanish and British schools, claimed, as did the histories of his colleagues, to illuminate the culture of contemporary Europe. Believing that the past in the form of history was necessary for the understanding of the present, Fiorillo clearly envisioned a history of art as integral - perhaps even indispensable - to the larger history his colleagues were 
writing. The question has, in fact, been raised as to whether a Western history could have becn possible without the researches of art history and its integration into university curricula. ${ }^{62}$ In the case under discussion here, it seems that the new History might indeed have required an art (or artefactual) history in order for it to establish both a suitable story of humankind and the place of European culture within that story. There can be no doubt that this fledgling academic discipline would soon take its place in what Stephen Bann has termed the nineteenth century's dominant "historical-mindedness" as a paradigmatic form of knowledge, ${ }^{63}$ particularly in its contributions to the conceptualizing/visualizing of the past in the modern university. This conceptualization ensured that those Western cultural objects designated as good, civilized and beautiful would find (and keep) their place in a new order, particularly in the form of a university education to those who were to shape this new social order in late eighteenth- and early nineteenth-century Germany and Western Europe. Fiorillo's art history, as he himself put it, was not only a true academic work but would also "equip" his male students, especially those who would have the luxury of travel, "with the knowledge required for visiting galleries". ${ }^{64}$ Here, they could recognize and appreciate not only masters and masterpieces, but also the discourses of progress and the "civilized" which the museum pieces represented. Fiorillo's text thus situates itself as a synthesis of the art historical traditions of Vasarian-based chronicle and Winckelmannian stylistic and historical analysis, as well as participating in the now well-established educational goal of "understanding the past" through histories written by university-based scholars. Not only did Fiorillo's art history "illuminate" the deeply intertwined conceptions of history and of civilized "man" being written at the university of Göttingen, but it bestowed upon its students that "useful" knowledge about European art and culture - and thus the identity of the European subject - expected of the university-educated.

\section{Acknowledgements}

I would like to thank the Social Sciences and Humanities Research Council of Canada for research support for this article.

\section{Notes}

1 For a recent discussion of Winckelmann and his art historical work, see Alex Potts, Flesh and the Ideal. Winckelmann and the Origins of Art History (New Haven and London, 1994).

2 For a stimulating postmodern analysis of history in the Western tradition, see Keith Jenkins, Why History? (London and New York, 1999). See also F.R. Ankersmit, Historical Representation (Stanford, 2001) and Stephen Bann, Romanticism and the Rise of History (New York, 1995).
3 For a good overview, see Hans Erich Bödeker et al., Aufklärung und Geschichte. Studien zur deutschen Geschichtswissenschaft im 18. Jahrhundert (Göttingen, 1986).

4 For a discussion of Winckelmann's self-image as a "free scholar and man of letters" in Rome, see Potts, Flesh and the Ideal, 188-201, particularly 196-97.

5 There is much literature, especially in German, on the eighteenthcentury development of history as a scholarly discipline. See H.W. Blanke, Historiographiegeschichte als Historik (Stuttgart-Bad Canstatt, 1991); H.W. Blanke, D. Fleischer and J. Rüsen, eds, "Historik als akademische Praxis. Eine Dokumentation der geschichtstheoretischen Vorlesungen an deutschsprachigen Universitäten von 1750-1900," Dilthey-Jahrbuch für Philosophie und Geschichte der Geisteswissenschaften, 1 (1983), 182-255. In English, see Konrad $\mathrm{H}$. Jarausch, "The Institutionalization of History in 18thCentury Germany," in Bödeker et al., Aufklärung und Geschichte, $25-48$.

6 Hans Belting provides the following description: "A 'history of art', then, transforms a notion of art nurtured in the works of art into the subject of a historical account, independent of and only reflected in the works. The historicization of art became in this way the general model for the study of art." Hans Belting, The End of the History of Art?, trans. Christopher Wood (Chicago and London, 1987), 6 .

7 The genesis of historicism has been the subject of much historiographical writing. For a good recent overview, see Ankersmit, Historical Representation, 123-48.

8 Nathan Uglow, The Historian's Two Bodies. The Reception of Historical Texts in France, 1701-1790 (Aldershor, Burlington USA, Singapore, Sydney, 2001), vi.

9 Johann Dominicus Fiorillo (1748-1821) was born in Hamburg of Italian parents and began his artistic studies at the age of 11 at the drawing school established by the Margrafen Friedrich of Bayreuth. In 1761 he went to Rome to study painting with Pompeo Batoni, and later went on to Bologna, where he studied architecture and perspective. Upon returning to Germany, he became court history painter at Braunschweig; in 1781 he began his affiliation with the university of Göttingen, first as curator of the print collection, then as a teacher of art history. Full biographical information can be found in Johann Stephan Pütter, Versuch einer academischen Gelehrten-Geschichte von der Georg-Augustus-Universität zu Göttingen, 4 vols (Götringen, 1765-1838), II (1788), 198; III (1820), 370. See also Metzler Kunsthistoriker Lexikon: zweihundert Porträts deutschsprachiger Autoren aus vier Jahrhunderten (Stuttgart, 1999), 90-92.

10 Johann Dominicus Fiorillo, Geschichte der zeichnenden Künste von ihrer Wiederauflebung bis auf die neuesten Zeiten, 5 vols (Götringen, 1798-1808). A four-volume Geschichte der zeichnenden Künste in Deutschland und den vereinigten Niederlanden was published in 1815-20, but not as part of the series under discussion here.

11 For a complete list of Fiorillo's published works, see Antje Middeldorf Kosegarten, ed., Johann Dominicus Fiorillo. Kunstgeschichte und die romantische Bewegung von 1800 (Göttingen, 1997), 478-81.

12 Geschichte der Künste und Wissenschaften seit der Wiederherstellung 
derselben bis zu Ende des 18ten Jahrhunderts, von einer Gesellschaft gelehrter Männer ausgearbeitet, 57 vols (Göttingen, 1796-1850).

13 Jarausch, "Institutionalization," 31.

14 For a useful recent consideration of the place of disciplinary endeavour, in terms of art history as well as philosophy, see Mark Cheetham, Kant, Art, and Art History: Moments of Discipline (Cambridge, 2001), especially 20-21 for pertinent references to both Göttingen and Fiorillo.

15 Most recently, Kosegarten, cd., Johann Dominicus Fiorillo; an exception is the essay by Otto Gerhard Öxle, "Aufklärung und Historismus: Zur Geschichtswissenschaft in Göttingen um 1800," $28-56$.

16 Silvio Vietta, ed., Romantik und Renaissance: die Rezeption die italienischen Renaissance in der deutschen Romantik (Stuttgart, 1994); an exception is the essay by Archim Holter, "Johann Dominik Fiorillos Geschichte der zeichnenden Künste und ihr Bild der Renaissance," 95-115, which discusses Fiorillo's work on the Renaissance in the context of eighteenth-cencury historical theories.

17 For a contemporary claim for Göttingen's fame, see C. Meiners, Über die Verfassung, und Verwaltung deutscher Universitäten (Göttingen, 1801), iv-v.

18 For a history of Göttingen university, see Gotz von Selle, Die Georg-August-Universität zu Göttingen 1737-1937 (Göttingen, 1937). See also Pütter, Versuch, I, 5-12.

19 Bill Readings has, for instance, argued that the modern university owes its existence at least in part to German idealist thought, with Kant's vision of reason at its centre. See Bill Readings, The University in Ruins (Cambridge, MA, 1996), chapter 9.

20 For a discussion of this crisis, see Charles E. McClelland, State, Society, and University in Germany, 1700-1914 (Cambridge, 1980), $28 \mathrm{ff}$. See also Michael J. Hofstetter, The Romantic Idea of a University. England and Germany, 1770-1850 (Basingstoke, New York, 2001), 1-7.

21 Pütter, in his history of the university, quite clearly makes this point when he states that the Georgia Augusta's principal aim was to "ban all pedantry from scholarship" (“... ein vorzügliches Augenmerk dieser Universität gewesen ... alles pedantische von der Gelehrsamkeit zu verbannen"), Pütter, Versuch, I, 5.

22 This change is most recently discussed in Peter A. Vandermeersch, "Teachers," in Hilde de Ridder-Symöns, ed., A History of the University in Europe (Cambridge, 1996), 229-31. See also McClelland, State, Society and University, 30ff.

23 Laurence Brockliss, "Curricula," in Ridder-Symöns, ed., A History of the University, 568. See also Martin Bernal, Black Athena. The Afroasiatic Roots of Classical Civilization, 2 vols (New Brunswick, New Jersey, 1987), I, 215.

$24 \mathrm{McCl}$ clland, State, Society and University, 47-48. For a table representing the social origin of students at Göttingen from 1776 to 1797, see Jarausch, "Institutionalization," 30. Those students originating from the nobility and the Bildungsbürgertum (educated middle class) represented two-thirds of the student population at Göttingen during the eighteenth century.

25 Pierre Bourdieu and Jean-Claude Passeron, Reproduction in Education, Society and Culture, trans. Richard Nice (London and Beverly
Hills, 1977), 114.

26 Bourdieu and Passeron, Reproduction, 130.

27 Horst Walter Blanke and Dirk Fleischer, eds, Theoretiker der deutschen Auflkärungshistorie, I (Stuttgart-Bad Canstatt, 1990), 44. For a similar claim, see also McClelland, State, Society, and University, 40-45, and John Gascoigne, Science, Politics and Universities in Europe, 1600-1800 (Aldershot, Brookfield USA, Singapore, Sydney, 1998), 9.

28 This shift, as well as the development of the natural sciences in the seventeenth and eighteenth centuries, is the topic of Michel Foucault's The Order of Things: An Archaeology of the Human Sciences (London, 1974).

29 For complete information on Blumenbach, see Thomas Bendyshe, The Anthropological Treatises of Johann Friedrich Blumenbach (London, 1865). For a discussion of Blumenbach, Meiners and their thcorizing regarding race, see Frank W.P. Dougherty, "Christoph Meiners und Johann Friedrich Blumenbach im Streit um den Begriff der Menschenrasse," in Guncer Mann and Franz Dumont, eds, Die Natur des Menschen. Probleme der Physischen Anthropologie und Rassenkunde (1750-1850) (Stuttgart, New York, 1990), 89111.

30 For an in-depth discussion of Gatterer (1727-99) and his conception of history, see Peter Hans Reill, "Johann Christoph Gatterer," in H.-U. Wchler, ed., Deutsche Historiker, VI (Göttingen, 1980), 7-22. For Schlözer, see Ursula A.J. Becher, "August Ludgwig von Schlözer," in Wehler, ed., Deutsche Historiker, VII, 7-23.

31 Bernal, Black Athena, I, 215.

32 Challenges to Bernal's argument can be found in Mary R. Lefkowitz and Guy MacLean Rogers, eds, Black Athena Revisited (Chapel Hill, 1996).

33 Johann Gottfried Eichhorn, ed., Allgemeine Geschichte der Cultur und Litteratur des neuern Europa, Allgemeinen Geschichte der Künste und Wissenschaften, I (Göttingen, 1796), v: “... auf welche Weise [hat] unser Welttheil nach und nach zu seiner heutigen Cultur gekommen? wie sein gesellschaftlicher Zustand aus seiner ersten Rohheit stufenweis herausgetreten, und darauf in Verbesserung, Veredelung und Verfeinerung allmählig übergegangen?"

34 For a complete listing of included "histories", see Pütter, Versuch, III (1820), 42-54.

35 As quoted from Schlözer's Weltgeschichte nach ihren Haupttheilen im Auszug und Zusammenhange (Görtingen, 1785) in Becher, "August Ludwig von Schlözer," 14: “... in ihrer successiven Entstehung, Veredlung und Verschlimmerung auf allen ihren Wegen, von Ländern zu Ländern, von Volke zu Volke, von Zeitalter zu Zeitalter, nach ihren Ursachen und Wirkungen nach(zu)spüren."

36 Meiners, Über die Verfassung, II, 148.

37 J.D. Fiorillo, Beschreibung der Gemählde-Sammlung der Universität $z u$ Göttingen (Göttingen, 1805), xiii: “... [dass] die Universitäten keine Kunstschulen sind".

38 Fiorillo, Geschichte der zeichnenden Künste von ihrer Wiederauflebung, I, vi.

39 Fiorillo, Geschichte der zeichnenden Künste von ihrer Wiederauflebung, I, vi-vii.

40 As quoted in Georg G. Iggers, "The European Concext of German 
Enlightenment Historiography," in Bödeker et al., Aufklärung und Geschichte, 238.

41 Fiorillo, Geschichte der zeichnenden Künste von ihrer Wiederauflebung, I, vi-vii.

42 The concept of progress as part of the interpretation of society had already been well established by the French philosophes, particularly Voltaire in his Essai sur l'histoire generale et sur les moeurs et l'esprit des nations (Geneva, 1756); Schlözer was, for instance, a kcen follower of Voltaire's ideas. Kant's 1773-74 lectures on anthropology, which would later be published as Anthropologie in pragmatischer Hinsicht abgefasst (Königsberg, 1798) also centred on this notion.

43 Fiorillo, Geschichte der zeichnenden Künste von ihrer Wiederauflebung, I, 2. “... ob man einen gemeinschaftlichen Ursprung des ganzen Menschengeschlechts von einem Stammvater annimmt oder nicht ... Lässt man hingegen kein Urvolk gclten, so werden mehrere Völker gleichen Anspruch auf die erstc Erfindung der Künste machen können; sie sind ohngefähr denselben Weg gegangen, ohne von einander gelernt zu haben."

44 Fiorillo, Geschichte der zeichnenden Künste von ihrer Wiederauflebung, I, xii. "umfassenden Überblick, der für die allgemeine Geschichte so nothwendig ist".

45 Fiorillo, Geschichte der zeichnenden Künste von ihrer Wiederauflebung, I, xii.

46 For a recent discussion of this notion in the context of history and modernity, see Kathleen Wilson, "Pacific Modernity," in Colin Jones and Dror Wahrman, cds, The Age of Cultural Revolutions (Berkeley, Los Angeles, London, 2002), 62-93.

47 A case in point is Schlözer's description of this process in his Weltgeschichte, where he writes of "Paper, powder and trade ... book publishing, freedom and industry" as "European arts that have been carried by the Spaniards and the British across the ocean to the new world in order to adorn the globe; in the course of centuries Canada will be what Germany is today." [translation mine] (as quoted in Becher, "August Ludwig von Schlözer," 17.)

48 Pütter, for instance, noted already in 1765 that the library at the Georgia Augusta was well stocked with "einem reichen Vorrath von Reisebeschreibungen und geographischen Werken". (Pütter, Versuch, I, 1765, 216). For a full account of the Göttingen library and its central place in eighteenth-century Europe, sec Georg Schwedt, ed., Zur Geschichte der Göttinger Universitätsbibliothek (Göttingen, 1983). See also Johann Beckmann, Litteratur der ältesten Reisebeschreibungen (Göttingen, 1807-10) for an account of travel literature available in Germany during the eighteenth century.

49 Blanke and Fleischer, eds, Theoretiker, II, 756.

50 For an outline of this correspondence, sec Warren R. Dawson, ed., The Banks Letters (London, 1958), $110 \mathrm{ff}$. See also John Gascoigne, Joseph Banks and the English Enlightenment. Useful Knowledge and Polite Culture (Cambridge, 1994), 149-52.
51 Fiorillo, Geschichte der zeichnenden Künste von ihrer Wiederauflebung, I, 3. The publications Fiorillo refers to are Cook's Voyages in John Hawkesworth, An Account of the Voyages undertaken by the order of his present Majesty for making discoveries in the Southern Hemisphere, and successively performed by Commodore Byron, Captain Wallis, Captain Carteret, and Captain Cook... (London, 1773); John Meares, Voyages made in the years 1788 and 1789 from China to the North West Coast of America (London, 1790)(German translation 1790); Nathaniel Portlock, A Voyage round the World, but more particularly to the north-west coast of America: performed in 1785 (London, 1789) (German translation 1791); Johann Reinhold Forster, Observations made during a Voyage round the World, or, Physical geography, natural history, and other philosophy (London, 1778) (German translation, 1784). Fiorillo's footnotes regarding these and similar publications indicate that he was able to read English texts.

52 Fiorillo, Geschichte der zeichnenden Künste von ihrer Wiederauflebung, I, 3.

53 Fiorillo, Geschichte der zeichnenden Künste von ihrer Wiederauflebung, I, 2.

54 Fiorillo, Geschichte der zeichnenden Künste von ibrer Wiederauflebung, I, 2-4.

55 Fiorillo, Geschichte der zeichnenden Künste von ibrer Wiederauflebung, I $1,2$.

56 Fiorillo, Geschichte der zeichnenden Künste von ihrer Wiederauflebung, I, 2 .

57 Fiorillo, Geschichte der zeichnenden Künste von ihrer Wiederauflebung, I, 69-70.

58 Fiorillo, Geschichte der zeichnenden Künste von ihrer Wiederauflebung, I, 1.

59 Fiorillo, Geschichte der zeichnenden Künste von ihrer Wiederauflebung, II, 1801, xi. Fiorillo claims that other historics of the arts, Lanzi's in particular, were marred by "so viele Abtheilungen von Schulen und Epochen" that any larger understanding of them was lost.

60 Fiorillo, Geschichte der zeichnenden Künste von ihrer Wiederauflebung, II, 253.

61 Fiorillo, Geschichte der zeichnenden Künste von ihrer Wiederauflebung, II, xi.

62 Hans Robert Jauss raised the question in 1973 when he asked: “... ob die Geschichte der Kunst, die man zumeist als abhängige und 'arme Verwandte' der allgemcinen Historie anzusehen pflegt, nicht auch einmal der gebende Teil gewesen sein und künftig wieder ein mögliches Paradigma der geschichtlichen Erkenntnis werden kann." H.R. Jauss, "Geschichte der Kunst und Historie," in Rene Koselleck and Wolf-Dieter Stempel, eds, Geschichte-Ereignis und Erzählung (Munich, 1973), 178.

63 Bann, Romanticism and the Rise of History, 4.

64 Fiorillo, Beschreibung, vii. 